\title{
Caveolin-1 and Flotillin-1 Differential Expression in Clinical Samples of Renal Cell Carcinoma
}

\author{
Francesca Raimondo ${ }^{1, *}$, Davide Ticozzi Valerio ${ }^{1}$, Fulvio Magni $^{1}$, Roberto Perego ${ }^{1}$, Cristina \\ Bianchi $^{1}$, Cecilia Sarto ${ }^{2}$, Stefano Casellato ${ }^{3}$, Ester Fasoli ${ }^{4}$, Stefano Ferrero ${ }^{4}$, Ingrid Cifola ${ }^{5}$, \\ Francesco Rocco ${ }^{3}$, Marzia Galli Kienle ${ }^{1}$, Paolo Mocarelli ${ }^{1,2}$, Paolo Brambilla ${ }^{1,2}$ and Marina Pitto ${ }^{1}$
}

\begin{abstract}
${ }^{l}$ Department of Experimental Medicine, University Milano-Bicocca, Monza, Italy; ${ }^{2}$ University Department of Laboratory Medicine, University Milano-Bicocca, Hospital of Desio, Desio, Italy; ${ }^{3}$ Department of Urology, Hospital Maggiore IRCCS, Univ. of Milano, Milano, Italy; ${ }^{4}$ Department of Medicine Surgery and Dentistry, Pathological Anatomy, S. Paolo Hospital, Univ. of Milano, Milano, Italy and ${ }^{5}$ Dept. of Biomedical Sciences and Technologies and CISI, Univ. of Milano, Milano, Italy
\end{abstract}

\begin{abstract}
Caveolin-1 and flotillin-1 belong to plasma membrane microdomains. They are characterized by peculiar lipid and protein composition and are involved in fundamental cellular events such as: signal transduction, cell adhesion, lipid/protein sorting, and human cancer. We addressed caveolin-1 and flotillin-1 expression in 30 human renal cell carcinoma (RCC) and adjacent normal kidney (ANK) samples by SDS-PAGE and immunoblotting with specific antibodies. Significant caveolin-1 and flotillin-1 over-expression was found in RCC tissues compared to ANK, and was confirmed by immunohistochemistry. Caveolin-1 and flotillin-1 protein levels were found by 1-D, 2-DE, and MS to be increased also in RCC microdomain-enriched subcellular fractions purified from paired RCC and ANK samples.
\end{abstract}

Key Words: Caveolin, Flotillin, mass spectrometry, renal cell carcinoma, subcellular proteomics, two-dimensional electrophoresis.

\section{INTRODUCTION}

Caveolae and rafts are specialized plasma membrane microdomains that are enriched in cholesterol and sphingolipids and share peculiar physicochemical features, different from those of bulk membranes. Owing to such peculiar composition, both can be isolated as subcellular fractions relying on their detergent insolubility as detergent resistant membranes (DRM) [1, 2]. In particular, caveolae are flasklike membrane invaginations of $50-100 \mathrm{~nm}$, due to the oligomerization of their characteristic protein, caveolin, whereas rafts are flat membrane subdomains enriched in glycosyl phosphatidylinositol-linked proteins and signal transduction components [3]. Caveolins and flotillins are the two most representative families of mammalian microdomain-associated integral membrane proteins, both implicated in their supra-molecular organization [4-6]. Indeed, caveolins and flotillins are considered markers of caveolar and raft microdomains, respectively [7]. Given their crucial involvement in transport, cholesterol homeostasis, and signal transduction, caveolae and rafts are suspected to play an important role in various diseases, including cancer [8]. In particular, caveolin-1 (Cav-1) has been found highly expressed in some solid-tumour types in vivo and its expression has been associated with increased tumour-cell survival, aggressiveness, metastatic potential and suppression of apoptosis [9-

*Address correspondence to this author at the Department of Experimental Medicine, University Milano-Bicocca, Monza, Italy, Via Cadore 48, 20052 Monza, Italy; Tel: (+39)-02-64488217; Fax: (+39)-02-64488068;

E-mail: francesca.raimondo@unimib.it
14]. Moreover Cav-1 can also be secreted and detected in extracellular fluids [15]. Accordingly, the study of Cav-1 as potential marker seems to be highly relevant to cancer research, [16].

Renal cell carcinoma (RCC), a human kidney cancer arising from the proximal tubular epithelium, accounts for about $3 \%$ of all adult cancers in Western countries. Among RCC, the clear-cell type displays higher frequency. Since small localized tumours rarely produce symptoms the diagnosis of RCC is often delayed until the disease is well advanced. Moreover, RCC is associated with a high potential of metastasis and is resistant to both chemotherapy and radiotherapy, while nephrectomy remains the most effective treatment [17]. Therefore, it is important to identify differentially expressed proteins to be used as potential diagnostic and/or prognostic markers in RCC. A promising strategy is subcellular comparative proteomics that allows to enrich specific cell compartments and assess differences in protein expression patterns therein. In particular, even if a proteomic approach in the study of membrane proteins is very important, only a few studies approached the subproteomics of plasma membrane, given the known difficulties in efficiently recovering hydrophobic proteins after 2DE analysis [18, 19]. Thus, in the present study we investigated the expression of the two most typical membrane microdomain components, caveolin-1 and flotillin-1, in RCC and adjacent normal kidney (ANK) samples obtained after nephrectomy and in microdomain-enriched fractions prepared from these tissues, by a subcellular proteomic approach. 


\section{MATERIALS AND METHODS}

\section{Chemicals}

Milli-Q water was used for all solutions. Urea, dye reagent for protein assay, acrylamide, SDS, glycine and carrier ampholytes were purchased from Bio-Rad (Hercules, CA, USA); trifluoroacetic acid, ammonium bicarbonate, porcine trypsin, thiourea, CHAPS, DTE, DTT, iodoacetamide, Triton $\mathrm{X}-100$, Trizma-base, MES anti $\beta$-actin $\mathrm{pAb}$ and cholera toxin B HRP-conjugated were from SIGMA Chemical Co. (St. Louis, MO, USA); ACN, methanol, glycerol and HPTLC were from Merck (Darmstadt, Germany); amidosulfobetaine14 (ASB-14) and monoclonal anti Hsp27 antibody (Ab-1) were from Calbiochem (Bad Soden, Germany); IPG strips, Mini Dialysis kit, and Hybond-ECL nitrocellulose membrane were from Amersham Biosciences (Uppsala, Sweden). NuPAGE Bis-Tris mini gels, MES and MOPS SDS running buffer, LDS (lithium dodecyl sulphate) sample buffer, antioxidant, SeeBlue Plus2 Pre-stained standard and SimplyBlue SafeStain were supplied by Invitrogen (San Giuliano Milanese, Milan, Italy). Anti-protease inhibitor cocktail (Complete) was from Roche (Monza, Italy). Anti-Cav-1 polyclonal antibody, anti-Flot-1, and anti-transferrin receptor, (TfR) $\mathrm{mAb}$ were purchased from Transduction Laboratories (Lexington, KY, USA). Species-specific secondary peroxidase conjugated antibodies and ECL reagents were from Pierce (Rockford, IL, USA). ChemMate EnVision Detection kit was from Dako Cytomation (Glostrup, Denmark).

\section{Patients and Specimens}

Samples of primary RCC and homologous normal kidney tissues were surgically obtained from 30 patients, with their informed consent approved by the Local Research Ethics Committee. None of the patients had received previous chemotherapy. RCC was classified according to WHO recommendations [20] also using immunohistochemical techniques: only samples from diagnosed clear cell RCC were included in the study. Tumour staging and grading were performed according to established criteria, by a pathologist [21]. Immediately after removal, representative tumour (RCC) and homologous cortical tissue samples (ANK) were collected by the pathologist. In particular the term "RCC" pertains to pieces of tumoral mass, selected inside homogeneous areas and avoiding grossly necrotic or fibrotic parts. "ANK" (Adjacent Normal Kidney) refers to a portion of the healthy cortex of the same kidney, contiguous to the tumoral mass, because it is known that RCC originates from kidney cortical region. A minimum of $1 \mathrm{~cm}^{3}$ of tumour and normal cortex were placed in sucrose buffered solution $(250 \mathrm{mM}$ sucrose, $10 \mathrm{mM}$ Tris-HCl, $\mathrm{pH}$ 7.4, $1 \mathrm{mM}$ EDTA), kept on ice and immediately transferred to the laboratory.

\section{Subcellular Fractionation and Microdomain Isolation}

After nephrectomy, the fresh renal tissue samples obtained were submitted to subcellular fractionation through differential centrifugation; samples were kept on ice during all the subsequent steps. Briefly, surgical tissues were weighed, minced with scissors and washed in sucrose buffered solution (see above). From here on, all the solutions were supplemented with protease inhibitors. Homogenization was carried out by a manual glass/glass potter device in sucrose solution. After a first centrifugation at $1,000 \mathrm{xg}$, for
$10 \mathrm{~min}$, followed by two washings, the nuclear pellet $\left(\mathrm{P}_{1}\right)$ was discarded and the three pooled supernatants were centrifuged at $14,500 \mathrm{x} g$ for $15 \mathrm{~min}$. This yielded the post-nuclear plasma membrane-enriched fraction $\left(\mathrm{P}_{2}\right)$ [22]. From the correspondent supernatant $\left(\mathrm{Sn}_{2}\right)$, soluble cytoplasmic $\left(\mathrm{Sn}_{3}\right)$ and microsomal-enriched fractions $\left(\mathrm{P}_{3}\right)$ were prepared, by ultracentrifugation at $200,000 \mathrm{xg}$ for $40 \mathrm{~min}$. Detergent resistant membranes (DRM) were isolated from the $\mathrm{P}_{2}$ fraction, after treatment with cold Triton X-100 (1\%) in MBS buffer (25 $\mathrm{mM}$ MES buffer, $\mathrm{pH} 6.5,150 \mathrm{mM} \mathrm{NaCl})$. Detergent/protein ratio was always kept constant (5-6 $\mathrm{mg}$ of protein $/ \mathrm{ml}$ of $1 \%$ Triton X-100 in MBS buffer, for each sucrose gradient). The resulting lysate was brought to $40 \%$ sucrose by the addition of $80 \%$ sucrose in MBS and overlaid with two layers of $30 \%$ and $5 \%$ sucrose in MBS [23]. The discontinuous gradient was then centrifuged at $200,000 \mathrm{x} g$ for $19 \mathrm{~h}$ using a Beckman SW 41 rotor. For the analysis of the resulting gradient, 11 equal volume fractions were collected from the top to the bottom of the gradient. The fractions \#5-6, corresponding to the opalescent ring at the $30 \%-5 \%$ sucrose interface and enriched in microdomains (see results), were pooled and precipitated by ultracentrifugation at $440,000 \mathrm{xg}$ for $50 \mathrm{~min}$, after proper dilution in $10 \mathrm{mM}$ Tris- $\mathrm{HCl}, \mathrm{pH}$ 7.4. Protein content was assessed by BCA protein assay (Sigma).

\section{Electrophoresis (1DE and 2DE)}

Protein separation was performed with the $\mathrm{NuPAGE}^{\circledR}$ electrophoresis system. Homogenates and subcellular fractions were subjected to electrophoresis: proteins were separated on NuPAGE ${ }^{\circledR} 4-12 \%$ Novex Bis-Tris pre-cast gels, using MOPS SDS running buffer (Invitrogen). Two-dimensional electrophoresis (2DE) was accomplished on microdomain-enriched subfractions, $50 \mu \mathrm{g}$ of pelletted proteins for Coomassie Blue staining (SimplyBlue SafeStain, Invitrogen) and $5 \mu \mathrm{g}$ for immuno-blotting. The procedure for sample preparation was adapted in order to allow efficient recovery of membrane proteins. In detail, samples of the pelletted proteins were first processed with Mini dialysis kit in order to remove interfering substances and salts. Microdomain proteins were dissolved in lysis buffer (7 M Urea, $2 \mathrm{M}$ thiourea, $20 \mathrm{mM}$ Tris, in the presence of protease inhibitors) and dialyzed against the same buffer for $3 \mathrm{~h}$ under continuous stirring. Then detergents and a reducing agent were added to the sample (2\% CHAPS, $2 \%$ ASB- $14,1 \%$ DTE, $0.5 \%$ carrier ampholytes, final concentrations) and proteins were solubilized for 3 hours at room temperature. After centrifugation at $16,000 \mathrm{xg}$ at room temperature, samples were loaded onto nonlinear 3-10 IPG-strips $(7 \mathrm{~cm})$ [24]. According to the manufacturer's instructions, in the first dimension, a $20 \mathrm{kVh}$ run was applied after $15 \mathrm{~h}$ of rehydration (Biorad protein IEF cell). The second dimension was carried out on 4-12\% NuPAGE Bis-Tris minigels. Gels were stained with Simply Blue (Invitrogen) for subsequent MS analysis.

\section{Immunoblotting}

After 1DE and 2DE, proteins were blotted from minigels onto nitrocellulose membrane using a "tank" electrophoretic transfer apparatus (Hoefer, Amersham Biosciences). Membranes were stained with Ponceau $\mathrm{S}$ to assess protein loading [25]. After blocking with 5\% w/v non-fat milk in PBS pH 7.4 containing $0.2 \%$ Tween 20 , blots were incubated in the presence of antibody (anti Cav-1 1:5000; Flot-1 and Hsp27, 
1:250, $\beta$-actin and TfR 1:1000), followed by reaction with secondary HRP-conjugates and ECL detection (Supersignal, Pierce). Images were captured with a CCD camera, Image station 2000R Kodak (Eastman Kodak), and densitometric evaluation was performed by Kodak Molecular imaging software. The intensity values were normalized to $\beta$-actin, to correct for protein loading. The intensity values were further normalized to a sample lane, which was repeated in all blots to correct for the different blots used for different samples, and corrected for background. Finally, the immunoblotting results were checked to be comprised within the linear range by plotting Optical density against increasing amount of cellular proteins (data not shown).

\section{Lipid Analyses}

Aliquots $(200 \mu \mathrm{l})$ of each gradient fraction were dialyzed, lyophilised, and then submitted to lipid extraction [26]. After partitioning, the cholesterol recovered in the organic phase was chromatographed (solvent system: hexane:diethylether:acetic acid, 20:35:1, each by vol) on HPTLC plates and visualized by anisaldehyde reagent. To determine levels of GM1 ganglioside in each fraction, $2 \mu$ of each microdomain fraction were dot blotted on nitrocellulose and blocked as described [27]. After incubation with HRP-conjugated cholera toxin B (Sigma) $(1: 10,000)$, the spots were revealed by enhanced chemiluminescence.

\section{Digestion and Peptides Extraction}

The bands of interest were excised from the gel and placed in siliconized tubes. Gel slices were destained with two washing steps using $100 \mu \mathrm{L}$ of ammonium bicarbonate $25 \mathrm{mM}$ with $50 \%$ acetonitrile (freshly prepared) in a Thermomixer at room temperature $(700 \mathrm{rpm})$ for 20 minutes and the solution was discarded after each step. Fifty $\mu \mathrm{L}$ of a 10 $\mathrm{mM}$ solution of DTT in $25 \mathrm{mM}$ ammonium bicarbonate were then added to the gels and the tubes were incubated for 45 minutes in the Thermomixer at $56^{\circ} \mathrm{C}$. After discarding the DTT solution, $75 \mu \mathrm{L}$ of a $55 \mathrm{mM}$ solution of iodoacetamide were added to each tube and incubated in the dark at room temperature for 30 minutes. Gel slices were then washed again using $100 \mu \mathrm{L}$ of ammonium bicarbonate $25 \mathrm{mM}$ with $50 \%$ ACN three times. Gel pieces were dried in a SpeedVac for 20 minutes and $5 \mu \mathrm{L}$ of a $12.5 \mathrm{ng} / \mu \mathrm{L}$ trypsin solution in $25 \mathrm{mM}$ ammonium bicarbonate were added to each sample and incubated overnight in an oven at $37^{\circ} \mathrm{C}$. The first peptide extraction was carried out using $10 \mu \mathrm{L}$ of a $0,1 \%$ TFA solution, while the second one was carried out using a $50 \%$ acetonitrile, $0.1 \%$ TFA solution. The extraction solutions were mixed together and dried in the SpeedVac. For MALDI-TOF MS analysis peptides were resuspended in $2 \mu \mathrm{L}$ of $0.1 \%$ TFA, while for LC-ESI-MS/MS analysis $10 \mu \mathrm{L}$ of a $0.1 \%$ formic acid solution was used.

\section{Mass Spectrometry and Proteins Identification}

For MALDI-TOF MS analysis, $2 \mu \mathrm{L}$ of samples were mixed with an equal volume of a saturated HCCA (a-Cyano4-hydroxycinnamic Acid) matrix solution in 0.1\% TFA, 50\% ACN. This mixture was spotted onto the MALDI target plate near the PepMix ${ }^{\circledR}$ peptide calibration standard solution from Bruker Daltonics. The MALDI-TOF mass spectrometer was a Reflex IV ${ }^{\mathrm{TM}}$ from Bruker Daltonics equipped with a 337 nm Nitrogen laser operating at $10 \mathrm{~Hz}$. All spectra were acquired in reflector positive mode in an $\mathrm{m} / \mathrm{z}$ range from 760 to 4200 with FlexControl ${ }^{\circledR}$ 2.4. Obtained spectra were analyzed with the FlexAnalysis ${ }^{\circledR} 2.4$ software (Bruker Daltonics). The resulting mass lists were subjected to database search using Mascot vers. 2.1 on a local server (www.matrixscience.com) and ProFound (http://prowl.rockefeller.edu) for verification of results. MALDI-TOF spectra were searched against Swiss-Prot database (vers. 54.0) restricted to human taxonomy. Trypsin and carbamidomethylation of cysteine were set as digestion enzyme and fixed modification respectively; a tolerance of $100 \mathrm{ppm}$ and 1 missed cleavage were chosen as search parameters. The HPLC system is a 1100 series from Agilent (Palo Alto, CA) equipped with a $\mu$ flow HPLC pump splitter from SGE (Victoria, Australia) and an Onyx Monolithic HPLC column C18 $0.1 \times 150 \mathrm{~mm}$ from Phenomenex (Torrance, CA). Flow rate at the end of the column was about $1 \mu \mathrm{L} / \mathrm{min}$. Solvent A was a $0.1 \%$ formic acid solution and solvent B was ACN, 0.1\% formic acid. Peptides were eluted with $4 \%$ of buffer B up to $90 \%$ buffer B over 25 minutes in a linear gradient. This system was coupled with an Esquire 3000plus ion trap mass spectrometer from Bruker Daltonics equipped with an ESI ion source. For LC-ESIMS/MS analysis, $10 \mu \mathrm{L}$ of samples were injected using a loop injector. Helium was used as the collision gas. Peptides were analyzed in positive ion mode in an $\mathrm{m} / \mathrm{z}$ range of 200 2000. The mass spectrometer duty cycle was composed of one MS scan followed by three consecutive MS/MS scans of the three most intense ions in each MS scan. MS/MS spectra were limited to two scans per precursor ion followed by 0.5 minutes of exclusion. The obtained chromatograms were analyzed with DataAnalysis ${ }^{\circledR}$, vers. 2.4 , (Bruker) and the resulting mass lists were used for database search using $\operatorname{Mascot}^{\circledR} 2.1$ on a local server. MS/MS spectra were searched against the Swiss-Prot database (vers. 54.0) restricted to human taxonomy. Carbamidomethylation of cysteine was set as fixed modification and phosphorylation as variable modification, while trypsin as digestion enzyme. A tolerance of 2.0 Da was chosen for the precursor and 1.0 Da for fragments. ESI-TRAP was selected as instrument.

\section{Immunohistochemistry}

Normal and tumour kidney samples of 16 patients with clear cell renal carcinoma (RCC) were formalin-fixed and paraffin embedded. Five mm thick tissue sections were dewaxed, dehydrated in xylene and alcohol, and subjected to antigen retrieval by means of two 6 min microwave cycles in sodium citrate ( $\mathrm{pH}$ 6.0). Endogenous peroxidase was blocked by incubation for 10 min with $3 \%$ hydrogen peroxide in deionized water. Sections were then incubated for $1 \mathrm{~h}$ with anti-Cav-1 polyclonal antibody, at a dilution of 1:1000 and anti-Flot-1 monoclonal antibody, at a dilution of 1:100. Antigen-antibody detection was performed with an anti-mouse peroxidase-conjugated secondary antibody and revealed using the DAKO ChemMate EnVision Detection kit according to the manufacturer's instructions. Sections were stained with 3,3'-diamino-benzidine substrate and counterstained with haematoxylin. Finally, tissue samples were dehydrated with alcohol and xylene and slides were observed with light microscopy. Section controls were obtained by omitting the primary antibody or by using unrelated mouse monoclonal antibodies. Sections were scored by a pathologist. 


\section{Statistics}

Statistical analysis was performed by the Wilcoxon matched pairs test using Ministat 2000 (2.1 version, Pubblicazioni Medico Scientifiche, Udine, Italy) and GraphPad Prism 4.0 software (GraphPad Prism).

\section{RESULTS}

Clinical and pathological data of the studied patients are reported in Table $\mathbf{1}$. The patients display quite homogeneous clinical features, most of them were in early phases of disease, with no metastasis nor positive lymph nodes at the

Table 1. Clear Cell Renal Carcinoma Samples Analyzed in this Study and Corresponding Clinical Data; Cases are Listed in Order of Increasing Elapsed Time

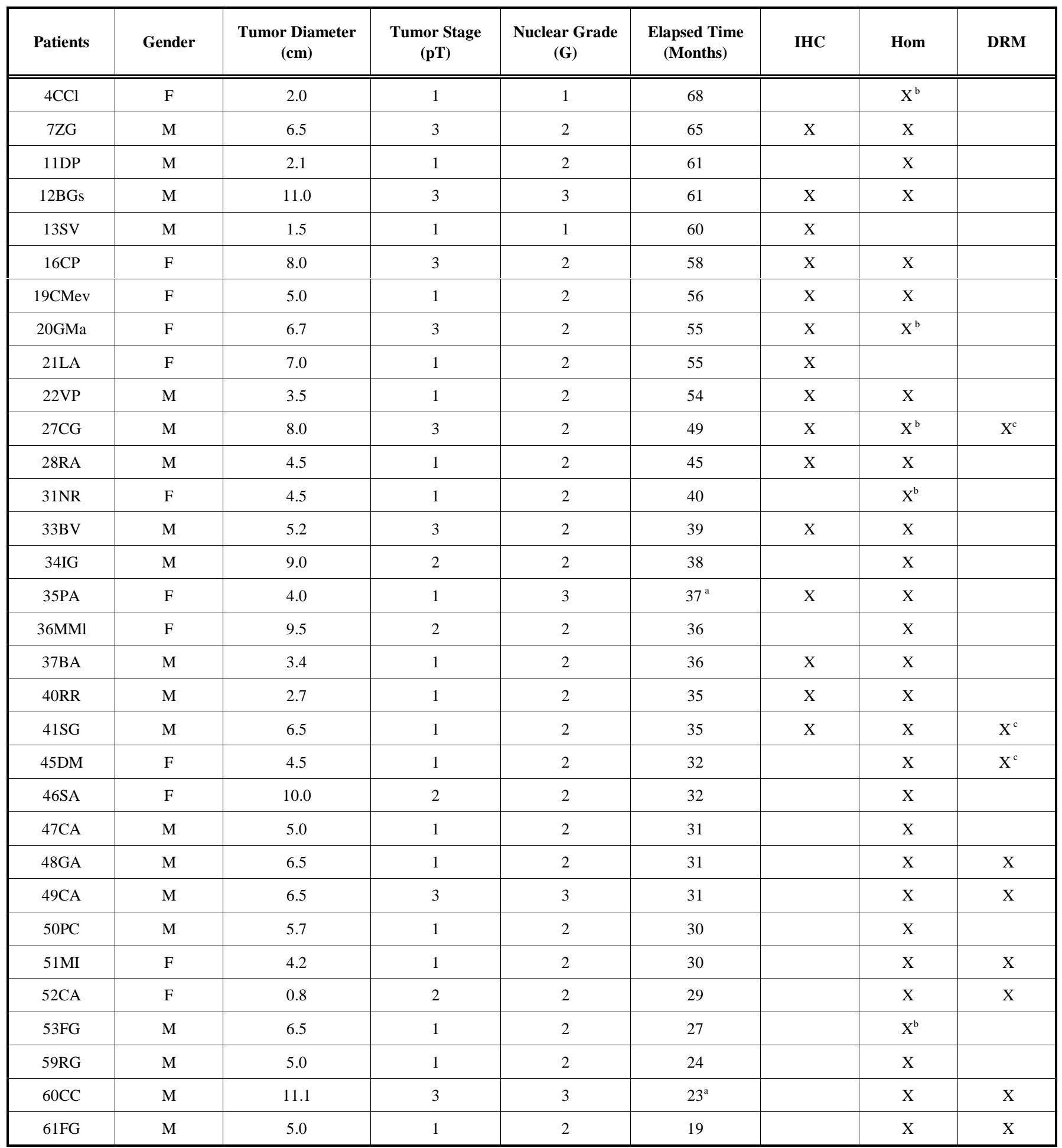

${ }^{(a)}$ Patients presenting tumor recurrence. IHC - Samples used for immunohistochemical analysis. Hom - Samples used for homogenate preparation and analysis (1DE/WB); ${ }^{\text {(b) }}$ samples shown in Fig. (1). DRM - Samples used for detergent resistant membrane preparation and analysis (1DE); ${ }^{(c)}$ samples analyzed also by $2 \mathrm{DE}$ 
moment of diagnosis and at present are free of disease, with the exception of two patients.

\section{Caveolin and Flotillin Protein Expression in Tissue Sam- ples}

First of all, caveolin and flotillin expression was studied in whole tissue homogenates prepared from a series of 30 clear cell RCC and normal adjacent cortex. Equal amounts of proteins were used for SDS-PAGE, followed by WB and detection with anti Cav-1 and anti Flot-1 antibodies, and anti $\beta$-actin for normalization: in most cases Cav-1 and Flot-1 bands resulted more intense in RCC tissue samples than in autologous ANK (five representative cases are shown in Fig. 1a). The densitometric analysis of Cav-1, Flot- 1 , and of $\beta$ actin bands for protein loading correction was performed. Caveolin was detected in two bands due to $\alpha$ and $\beta$ isoforms, as already described [28], that were quantified together (raw data of densitometric analysis are available as supplementary material, Table 1). Quantitative evaluation performed after normalization confirmed the results: an over-expression of Cav-1 and Flot-1 (Fig. 1b) is recorded in most clear cell tumor samples compared to control ones. The differences were statistically significant $(\mathrm{p}<0.0001$ both for $\mathrm{Cav}-1$ and for Flot-1). (Statistical analysis results are available as supplementary material, Table 2).

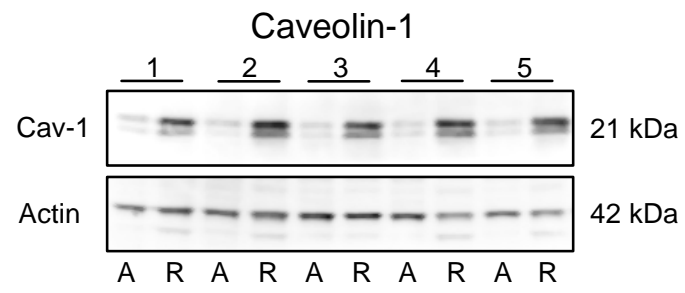

(a)

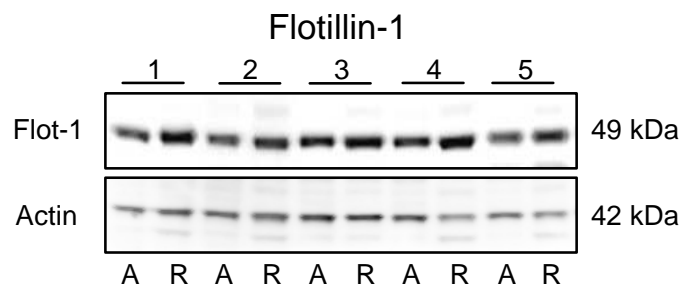

(b)

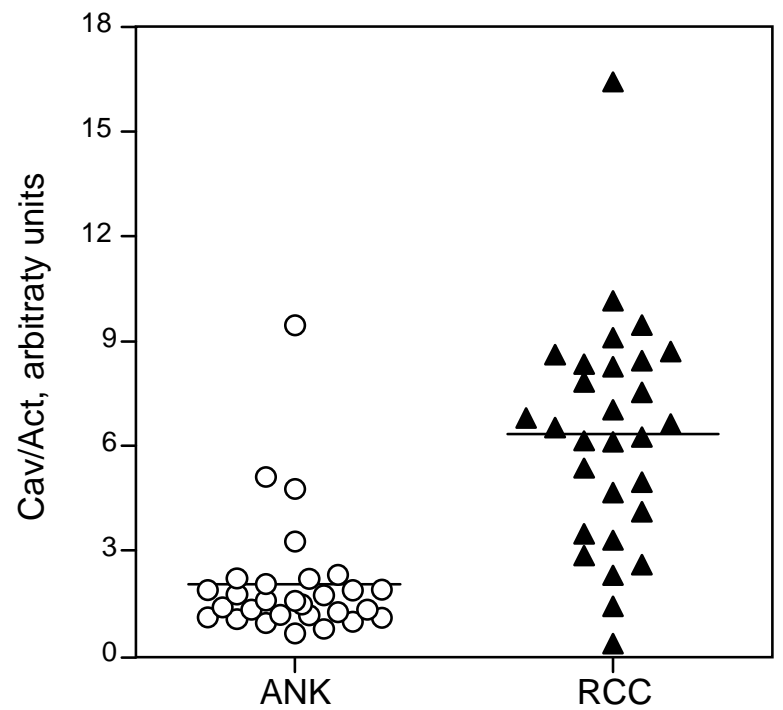

Caveolin and Flotillin Protein Levels in Microdomainenriched Fractions

We addressed Cav-1 and Flot-1 levels also in detergentresistant membranes (DRM) isolated from $10 \mathrm{RCC}$ and paired ANK. Analysis of the distribution of positive (Cav-1, Flot-1, and lipids) and negative markers (Transferrin receptor, actin) [29] along gradient fractions shown in Fig. (2), indicates that an efficient purification of microdomainenriched membranes was achieved in fractions \#5-6 (DRM) of both tumor and cortex tissue. Fig. (3) shows that the contamination of Hsp27 (cytoplasmic marker) is irrelevant in the microdomain-enriched fraction and its signal is marked in the cytosolic fraction $\left(\mathrm{Sn}_{3}\right)$; conversely, no reactivity for caveolin or flotillin is detectable in the $\mathrm{Sn}_{3}$ fraction from either sample.

Cav-1 and Flot-1 differential expression in RCC was confirmed in microdomain enriched fractions (Fig. 4), equal protein loading being ensured by Ponceau staining of WB membranes (data not shown). Moreover, on 1DE gels loaded with microdomain-enriched fractions prepared from 3 paired samples of RCC/ANK, it was possible to authenticate Cav-1 and Flot-1 identity by LC-ESI-MS/MS analysis after excision of Coomassie Blue (CB) stained bands (corresponding to WB positive signals) (Table 2). In the course of Cav-1 and Flot-1 analysis, other proteins were identified in the same

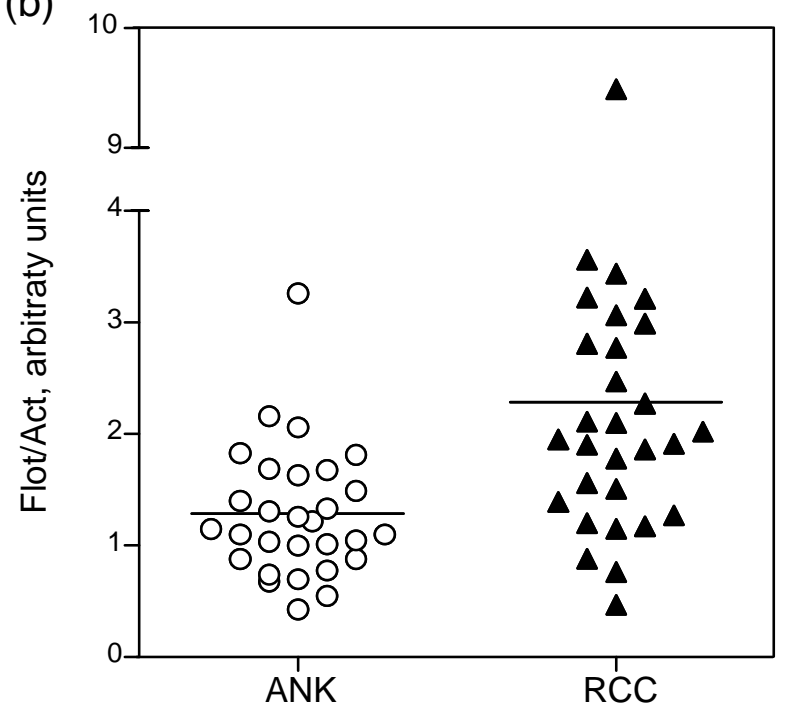

Fig. (1). Caveolin and flotillin protein expression in homogenates of RCC and ANK. Panel (a): western blotting analysis of 5 (out of 30 ) whole tissue homogenates (10 $\mathrm{g}$ protein/lane) prepared from matched normal kidney (A) and RCC (R) samples probed with antibodies to caveolin-1 (left) and flotillin-1 (right) as indicated, and simultaneously with antibodies to $\beta$-actin. Image acquisition was performed with a Kodak Digital Science 1D instrument, CCD camera equipped. Panel (b): densitometric quantification of bands relative to caveolin-1 (left) and flotillin-1 (right) in the whole tissue homogenates of 30 clear cell RCC and ANK, after SDS-PAGE immunodetection. Band intensity is normalized to $\beta$-actin. 


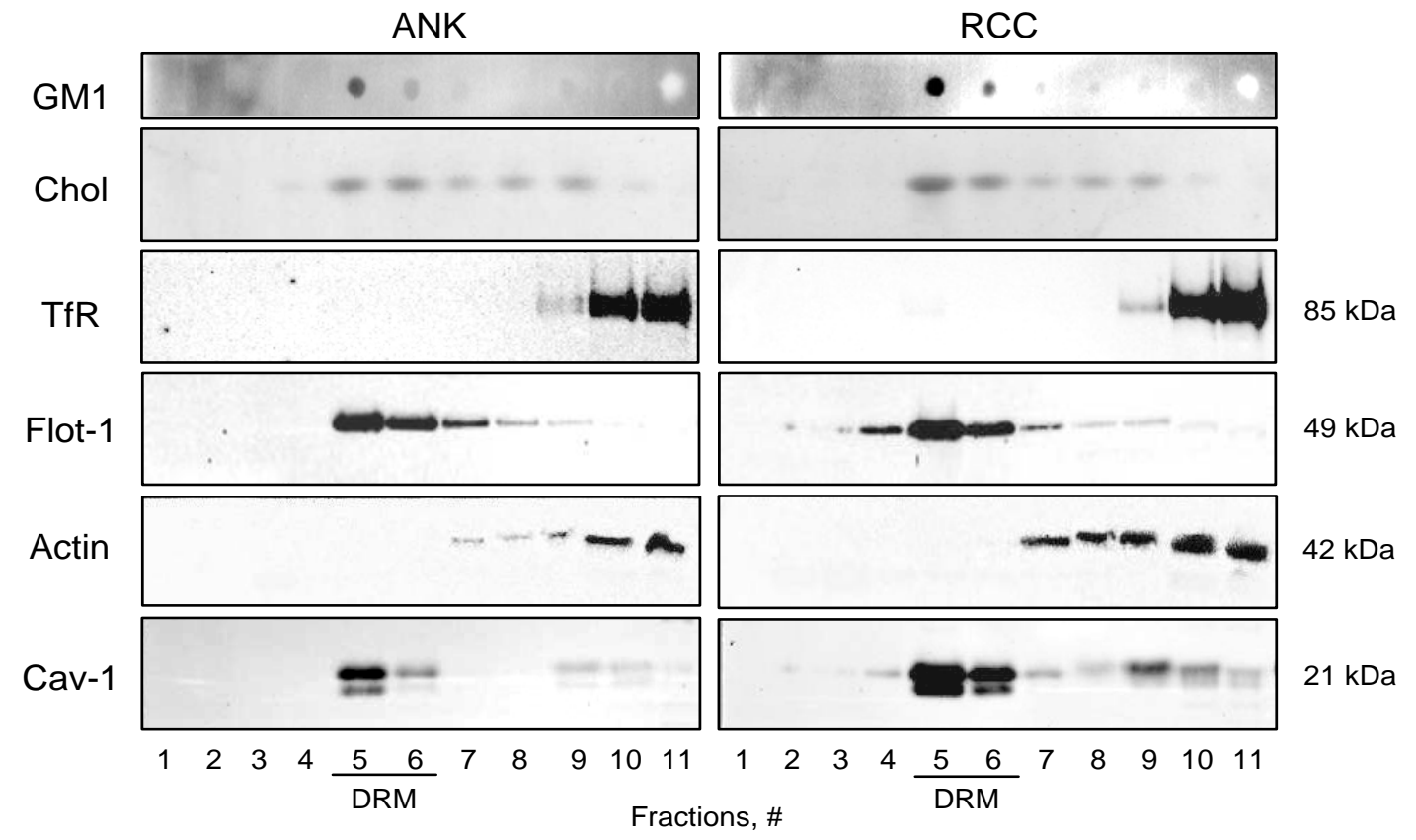

Fig. (2). Analysis of marker distribution along gradient fractions. Distribution of known lipid and protein markers of microdomains (GM1 ganglioside, cholesterol, (Chol), Cav-1 and Flot-1) in the 11 fractions collected from sucrose gradient performed following detergent treatment of the postnuclear fractions prepared from ANK and homologous RCC. The distribution of Transferrin receptor (TfR) and Actin, regarded as negative microdomain markers, is also shown. The same amount of each fraction, as volume, was loaded. A representative experiment (out of 5) is shown.

bands and are shown in Table $\mathbf{3}$. Their peptide sequences can be found in supplementary material (Tables 3-5).

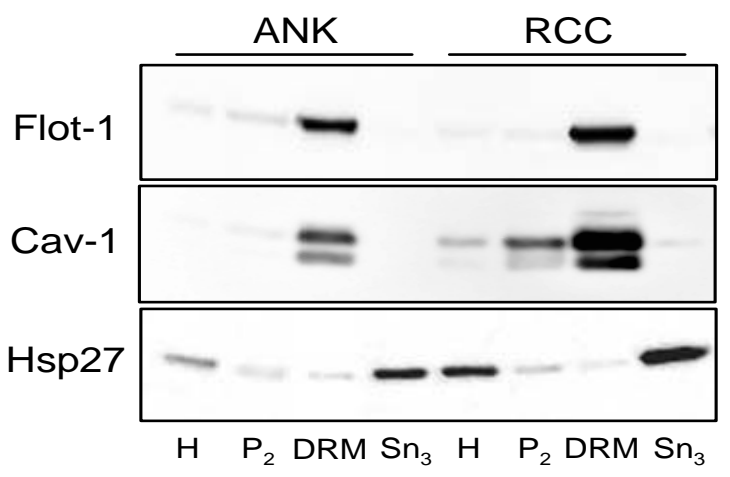

Fig. (3). Analysis of marker enrichment in the different subcellular fractions. Evaluation of Cav-1 and Flot-1 (microdomain positive markers) and Hsp27 (cytosol marker) enrichment in the different subcellular fractions prepared from the homogenates of ANK and RCC. H, homogenate; $\mathrm{P}_{2}$, postnuclear fraction; DRM, detergent resistant fraction, $\mathrm{Sn}_{3}$, cytoplasmic fraction. Equal amounts of each fraction were loaded, as protein $(2 \mu \mathrm{g})$. A representative experiment (out of 5) is shown.

Finally, microdomain-enriched fractions were analyzed by 2 -DE, followed either by immunodetection or Coomassie Blue staining. Fig. (5a) shows a 2-DE/WB analysis of the areas where positive caveolin and flotillin signal is recorded. From the comparison of spot intensity relative to RCC and ANK samples (exposed to ECL revelation for the same time), Cav-1 and Flot-1 over-expression in RCC could be confirmed. Their identity was ensured by mass spectrometry. For this purpose, 2DE mini-gels loaded with the same sam- ples were stained with CB. The stained spots corresponding to caveolin and flotillin positive signals in WB (Fig. 5b)

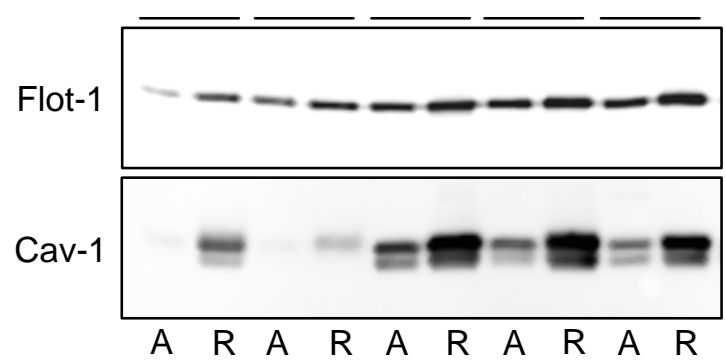

Fig. (4). Caveolin and flotillin protein levels in microdomainenriched fractions of RCC and ANK. Western blotting analysis of 5 (out of 10) microdomain-enriched fractions prepared from ANK (A) and homologous RCC (R) samples probed with antibodies to Caveolin-1 and Flotillin-1, as indicated. Equal amounts of each fraction were loaded, as protein $(2 \mu \mathrm{g})$.

were excised and processed by MALDI-TOF analysis (Table 4). Flotillin-1 (O75955) was positively identified $(\mathrm{p}<0.05)$ either by Mascot and by Profound algorithm in three spots from RCC (R8, R9 and R10) and one from ANK samples (A10), indicating that this protein is present at least in three different isoforms. Also Cav-1 (Q03135) was detected in three isoforms (spot R1, R3 and R4) with different $\mathrm{Mr}$ and $\mathrm{pI}$, but only in the 2DE prepared from RCC. None of the algorithms used allowed to discriminate amongst possible isoforms for these proteins. Cav-1 was positively identified in two spots (R1 and R3) only by Profound when search was restricted to Mr 19-22 and to pI 5-7. Spot R4 also contains Cav-1 as suggested by similarity of the mass spectrum of 
Table 2. Identification of Flotillin-1 and Caveolin-1 by LC-ESI-MS/MS

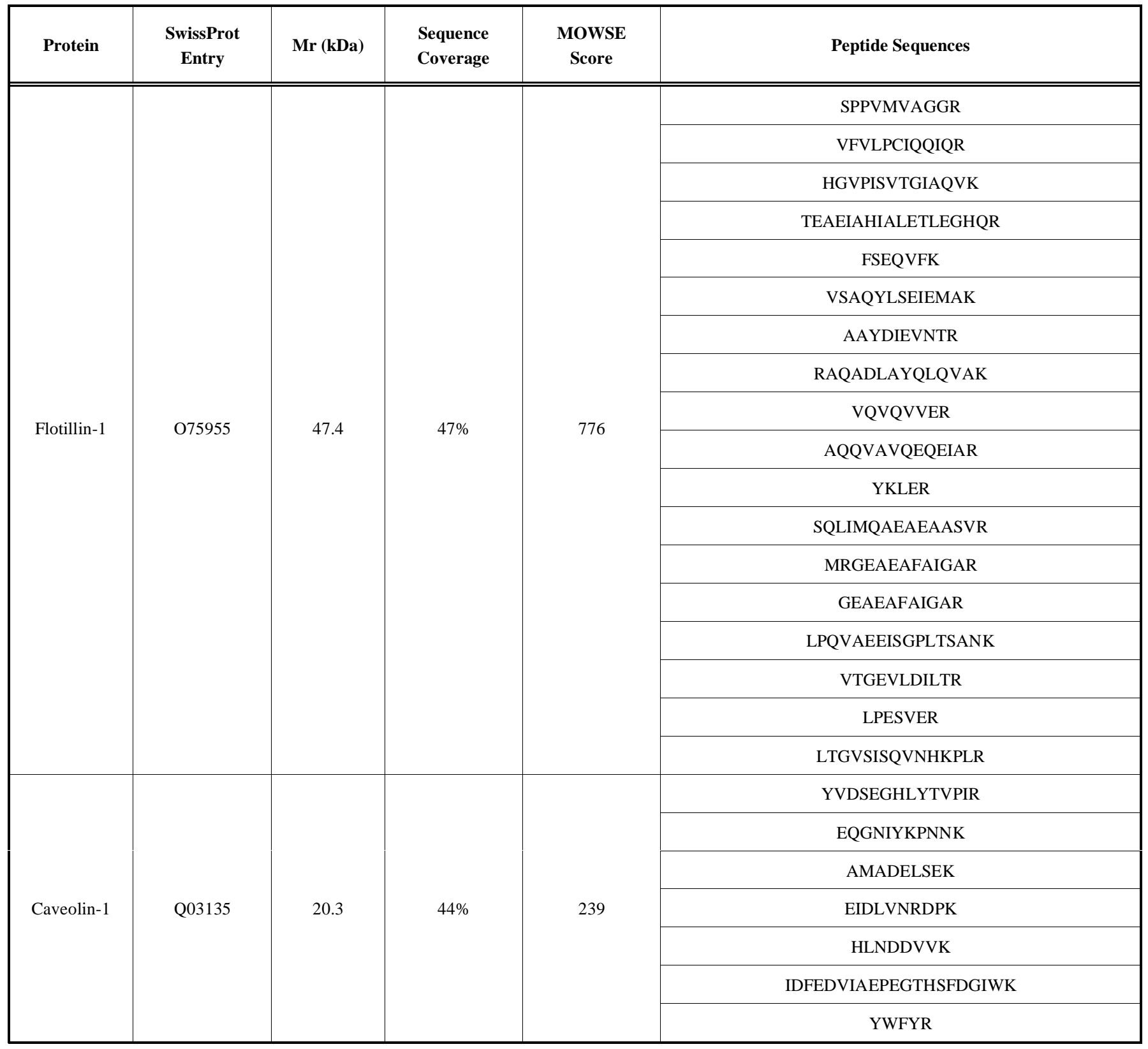

spot R4 with those of spot R1 and R3. No spot was recognizable in the corresponding area of the gel of the microdomain fraction obtained from the normal cortex. Therefore, no excision and MS analysis was performed in this case.

\section{Immunohistochemical Labelling of Renal tumour Tissues for Caveolin-1 and Flotillin-1}

In order to get confirmation of Cav-1 and Flot-1 overexpression in RCC by a morphological observation, fixed normal and tumour kidney tissue samples from 16 patients with conventional clear cell renal carcinoma were labelled for Cav-1 and Flot-1 and analyzed by immunohistochemical methods (Fig. 6). The 16 cases were scored for staining intensity semi-quantitatively and the statistical analysis confirmed the over-expression of Cav-1 (marked, with $\mathrm{p}=0.00048$ ) and
Flot-1 (weak, but significant, with $\mathrm{p}=0.00253$ ) in RCC samples (Table 5).

\section{DISCUSSION}

In the present study we demonstrate the over-expression of two typical microdomain protein components, namely caveolin-1 and flotillin-1, in RCC compared to homologous normal renal tissue. Cav-1 and Flot-1 expression was analyzed both in total homogenates and in microdomain enriched fractions prepared from freshly processed human tissues taken from living subjects. We could confirm the upregulation of Cav-1 and Flot-1 in RCC, by immunohistochemistry on tissues, and by mono- and 2DE analysis of the purified microdomain fractions through comparative subcellular proteomics. It has to be underlined that the MS identification of Cav-1 and Flot-1 was achievable only on the puri- 
fied microdomain fractions, being these proteins characterized by very low abundance in the total homogenates [30].

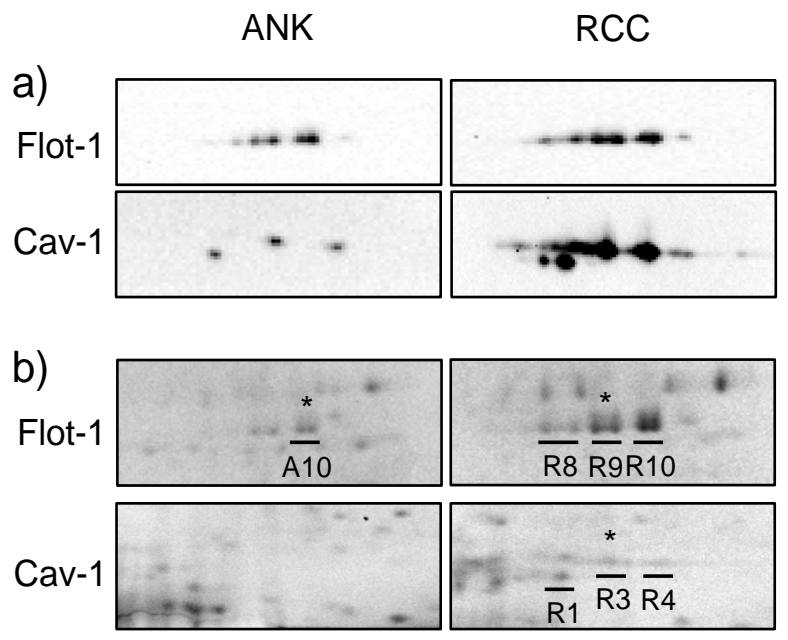

Fig. (5). 2-DE analysis of the microdomain-enriched fractions prepared from ANK and homologous RCC. Panel a): western blotting analysis of Cav-1 and Flot-1 after the same time of exposure for the paired samples ( $5 \mu \mathrm{g}$ of pelletted proteins). Panel b): $\mathrm{CB}$ staining $(50 \mu \mathrm{g}$ of pelletted proteins). The portions of the gel corresponding to Cav-1 and Flot-1 signals are shown. The marked spots were excised for MS analysis and identified as caveolin-1 (R$1,3,4)$ and flotillin-1 (R-8,9,10, A10) (see Table 2). One representative experiment (out of 3 ) is shown.
Moreover, other proteins co-migrating with Flot-1 and Cav-1 in bands excised from monodimensional gels were identified. Most of them are membrane (either integral, or lipid- or GPI-anchored) proteins, and some (renal dipeptidase, CD14, CD59 and Ras-related proteins) have been already described as microdomain-associated [31-34]; these results further validate the quality of the subfractions. Some mitochondrial proteins which may represent contamination were also identified, as already described. However, the possibility of the existence of mitochondrial rafts cannot be excluded [19]. It should be further pointed out that the expression of alfa-enolase, alpha B crystallin, and CD59 glycoprotein precursor, such as the Ras-Raf/MEK/ERK pathways were already reported as being involved in cancer, and in particular, in RCC [35-38].

Several reports indicate that Cav-1 (and caveolae) have a role in cancer development and progression. In fact, in a series of "in vivo" studies authors found caveolin up-regulation in several tumors, such as adeno-carcinomas of the prostate, breast [14], lung [10,39], and oesophageal squamous cell carcinoma [12]. Moreover, some recent papers report Cav-1 over-expression in RCC and its correlation with prognostic factors [40-45]. However, these latest studies were all undertaken using only immunohistochemical evaluation, and in most cases, caveolin over-expression was recorded in the cytoplasm of renal carcinoma cells. Our study, relying on subcellular fractionation, allows a more precise localization. Indeed, no signal for caveolin was detectable in the cytosolic fraction both from ANK and RCC in immunoblotting ex-

Table 3. Proteins Identified at the Level of Flot-1 and Cav-1 Positive Bands in RCC and ANK DRM Fractions

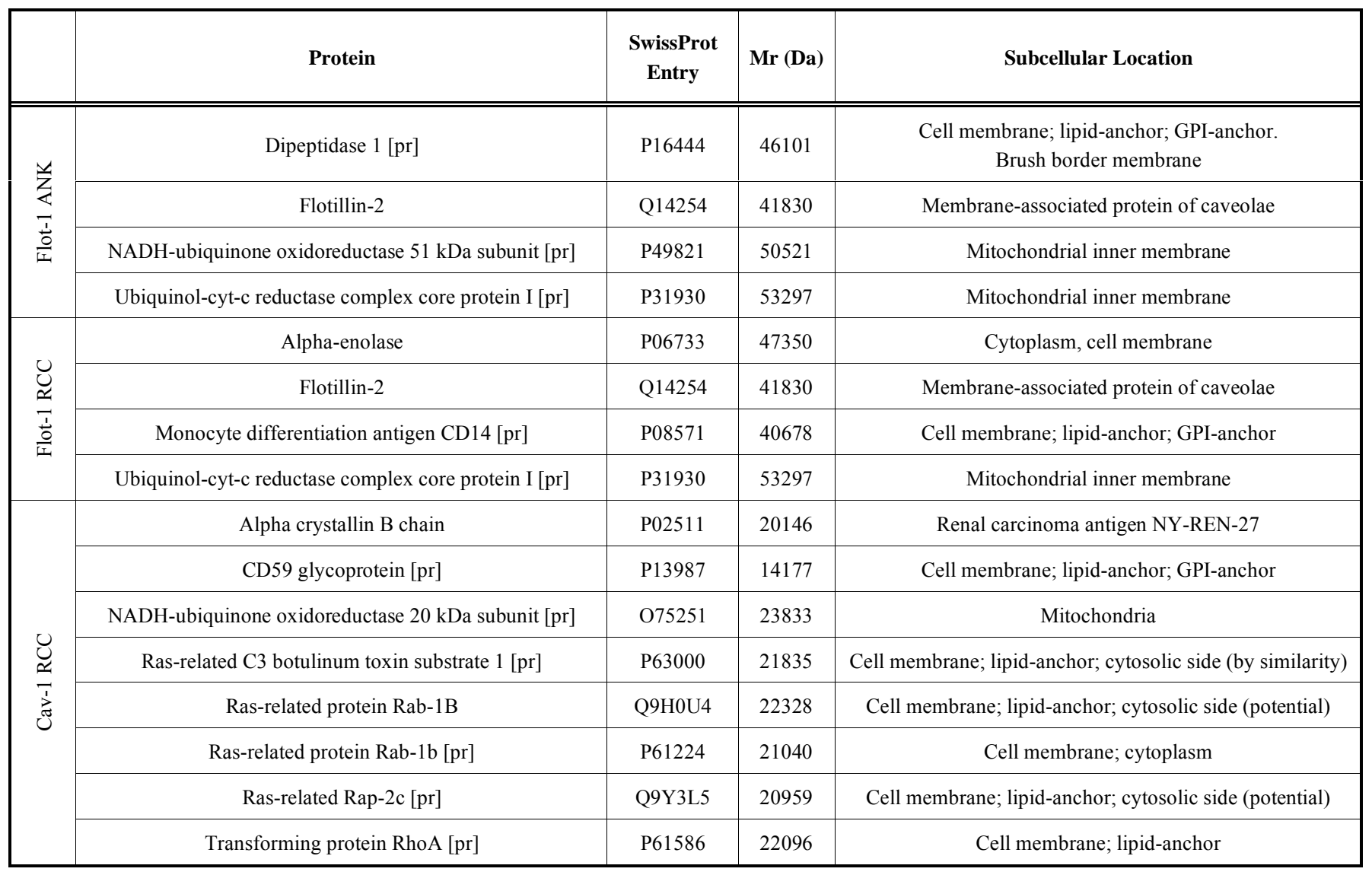


Table 4. Identification of Flotillin-1 and Caveolin-1 by MALDI-TOF Analysis

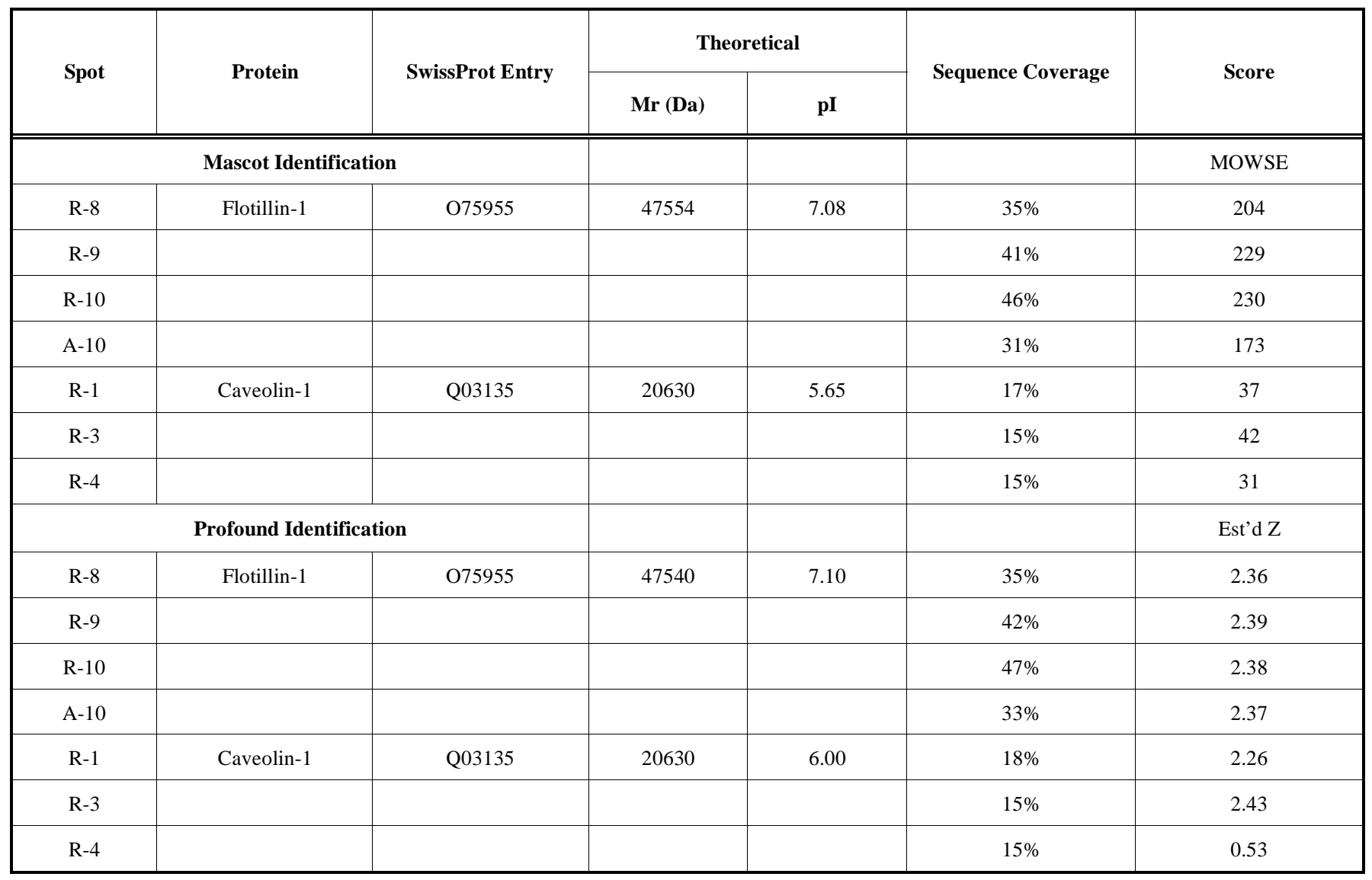

periments. This means that, although the presence of minor amounts of intracellular Cav-1 is confirmed in different cellular models, it may derive from intracellular membranebound Cav-1 [46, 47]. Therefore, our data provide the first demonstration of caveolin over-expression in RCC caveolar microdomains.

Table 5. Flotillin-1 and Caveolin-1 Expression Evaluated by IHC

\begin{tabular}{|c|c|c|c|c|}
\hline \multirow{2}{*}{ Sample No. } & \multicolumn{2}{|c|}{ Flotillin-1 } & \multicolumn{2}{c|}{ Caveolin-1 } \\
\cline { 2 - 5 } & ANK & RCC & ANK & RCC \\
\hline \hline $7 \mathrm{ZG}$ & N.A. & + & - & +++ \\
\hline $12 \mathrm{BGs}$ & +- & + & - & +++ \\
\hline $13 \mathrm{SV}$ & +- & + & - & +++ \\
\hline $16 \mathrm{CP}$ & + & ++ & - & + \\
\hline $19 \mathrm{CMev}$ & +- & ++ & - & + \\
\hline $20 \mathrm{GMa}$ & +- & + & - & ++ \\
\hline $21 \mathrm{LA}$ & + & + & - & +++ \\
\hline $22 \mathrm{VP}$ & +- & + & - & ++ \\
\hline $27 \mathrm{CG}$ & +- & + & - & +++ \\
\hline
\end{tabular}

\begin{tabular}{|c|c|c|c|c|}
\hline $28 \mathrm{RA}$ & ++ & ++ & + & +++ \\
\hline $33 \mathrm{BV}$ & + & ++ & - & +++ \\
\hline $35 \mathrm{PA}$ & +- & + & - & ++ \\
\hline $36 \mathrm{MMl}$ & + & +++ & - & ++ \\
\hline $37 \mathrm{BA}$ & +- & + & - & +++ \\
\hline $40 \mathrm{RR}$ & +- & +++ & - & +++ \\
\hline $41 \mathrm{SG}$ & + & + & - & + \\
\hline
\end{tabular}

-, no staining; +-, staining < 10\%; +, 10\%-40\%; ++, 40\%-70\%; +++, > 70\%.

With respect to flotillin-1, much less information is available from the literature than for caveolin. In fact, Flot-1 differential expression has been sporadically reported in pathologic conditions such as diabetes and malaria infection $[48,49]$. Therefore, our work is the first report of Flot-1 over-expression in RCC. Remarkably, a recent study, performed in a cell culture model, showed that Flot-1 overexpression strongly induced proliferation [50].

It would be interesting to evaluate the possible correlation between Cav-1 and Flot-1 differential expression and clinical parameters. However, it was not possible to draw any conclusion from our list of patients, since they show quite homogeneous clinical features and were all in early phases of disease. 


\section{Caveolin-1}

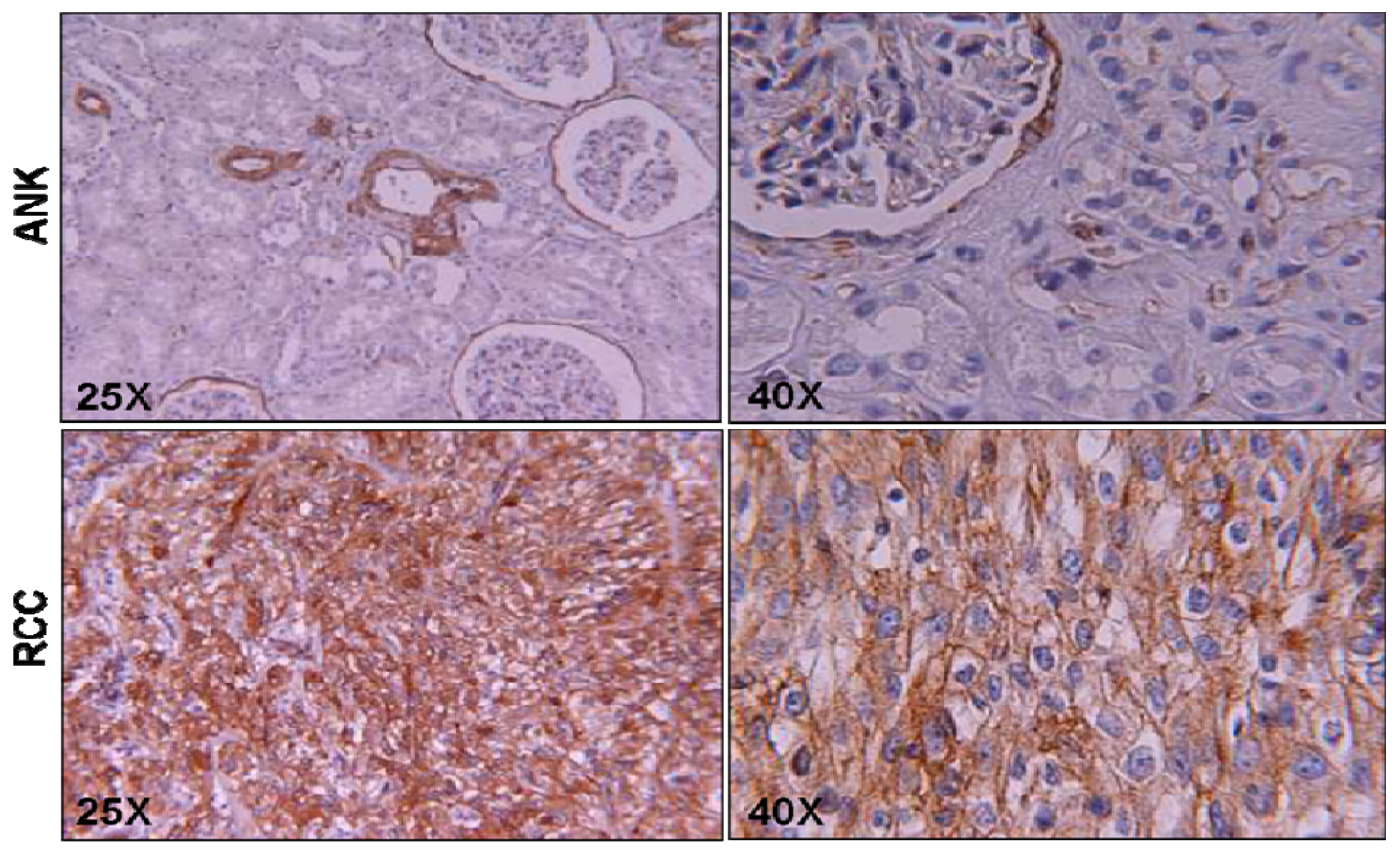

Flotillin-1

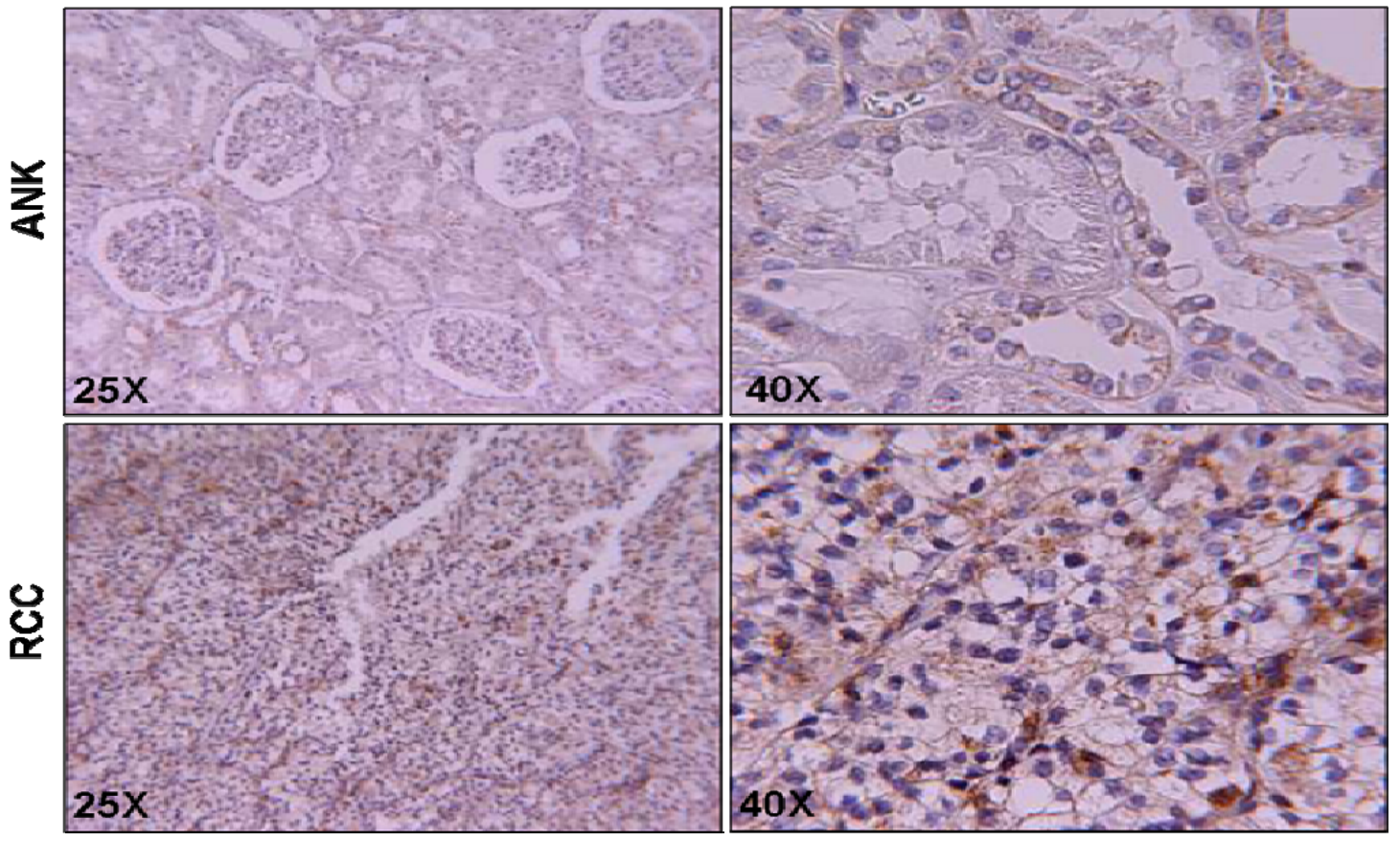

Fig. (6). Immunohistochemical analysis of Caveolin and flotillin in RCC and ANK. Images of Cav-1 and Flot-1 detected in tissue sections by immunohistochemical method. One representative image (out of 16) is shown.

Taken altogether, our data show the presence of higher amounts of Cav-1 and Flot-1, typical microdomain structural components, in renal cancer cell membranes than in ANK. This observation could lead to hypothesize the occurrence of an increased number and/or size of both caveolar and noncaveolar microdomains in RCC. The elucidation of this hypothesis deserves further investigation.

\section{CONCLUSIONS}

In conclusion, this study indicates that the strategy of comparative subcellular proteomics can be applied also at the plasma membrane level, in spite of the known difficulties in efficiently recovering hydrophobic proteins after 2DE analysis $[19,51]$. Since most of the tumour markers currently used, i.e., PSM, CEA, mucins and others, are actually 
membrane proteins, the recognition of increased amounts of plasma membrane proteins in RCC microdomains looks promising in view of new biological marker discovery.

\section{ACKNOWLEDGMENTS}

This work was supported by grants from MIUR (Rome, Italy, PRIN and FIRB). We thank Dr Paolo Ceppi and Dr Andrea Di Fonzo for technical assistance and Dr Rosanna Falbo for skilful language revision.

\section{SUPPLEMENTARY MATERIAL}

Supplementary material can be viewed at: http://www. bentham.org/open/toprotj

\section{REFERENCES}

[1] Masserini, M.; Ravasi, D. Role of sphingolipids in the biogenesis of membrane domains. Biochim. Biophys. Acta, 2001, 1532(3), $149-61$.

[2] Simons, K.; Ikonen, E. Functional rafts in cell membranes. Nature, 1997, 387 (6633), 569-72.

[3] Matveev, S.; Li, X.; Everson, W.; Smart, E. J. The role of caveolae and caveolin in vesicle-dependent and vesicle-independent trafficking. Adv. Drug Deliv. Rev., 2001, 49(3), 237-50.

[4] Parolini, I.; Sargiacomo, M.; Lisanti, M. P.; Peschle, C. Signal transduction and glycophosphatidylinositol-linked proteins (lyn, lck, CD4, CD45, G proteins, and CD55) selectively localize in Triton-insoluble plasma membrane domains of human leukemic cell lines and normal granulocytes. Blood, 1996, 87(9), 3783-94.

[5] Salzer, U.; Prohaska, R. Stomatin, flotillin-1, and flotillin-2 are major integral proteins of erythrocyte lipid rafts. Blood, 2001, 9(4), 1141-3.

[6] Bourguignon, L. Y.; Singleton, P. A.; Diedrich, F.; Stern, R.; Gilad, E. CD44 interaction with $\mathrm{Na}+\mathrm{H}+$ exchanger (NHE1) creates acidic microenvironments leading to hyaluronidase- 2 and cathepsin $\mathrm{B}$ activation and breast tumor cell invasion. J. Biol. Chem., 2004, 279 (26), 26991-7007.

[7] Langhorst, M. F.; Reuter, A.; Stuermer, C. A. Scaffolding microdomains and beyond: the function of reggie/flotillin proteins. Cell Mol. Life Sci., 2005, 62 (19-20), 2228-40.

[8] Cohen, A. W.; Hnasko, R.; Schubert, W.; Lisanti, M. P. Role of caveolae and caveolins in health and disease. Physiol. Rev., 2004, 84(4), 1341-79.

[9] Shatz, M.; Liscovitch, M. Caveolin-1: A tumor-promoting role in human cancer. Int. J. Radiat. Biol., 2008, 84 (3), 177-89.

[10] Ho, C. C.; Huang, P. H.; Huang, H. Y.; Chen, Y. H.; Yang, P. C.; Hsu, S. M. Up-regulated caveolin-1 accentuates the metastasis capability of lung adenocarcinoma by inducing filopodia formation. Am. J. Pathol., 2002, 161 (5), 1647-56.

[11] Ito, Y.; Yoshida, H.; Nakano, K.; Kobayashi, K.; Yokozawa, T.; Hirai, K.; Matsuzuka, F.; Matsuura, N.; Kakudo, K.; Kuma, K.; Miyauchi, A. Caveolin-1 overexpression is an early event in the progression of papillary carcinoma of the thyroid. Br. J. Cancer, 2002, 86(6), 912-6.

[12] Kato, K.; Hida, Y.; Miyamoto, M.; Hashida, H.; Shinohara, T.; Itoh, T.; Okushiba, S.; Kondo, S.; Katoh, H. Overexpression of caveolin-1 in esophageal squamous cell carcinoma correlates with lymph node metastasis and pathologic stage. Cancer, 2002, 94 (4), 929-33.

[13] Suzuoki, M.; Miyamoto, M.; Kato, K.; Hiraoka, K.; Oshikiri, T.; Nakakubo, Y.; Fukunaga, A.; Shichinohe, T.; Shinohara, T.; Itoh, T.; Kondo, S.; Katoh, H. Impact of caveolin-1 expression on prognosis of pancreatic ductal adenocarcinoma. Br. J. Cancer, 2002, 87(10), 1140-4.

[14] Yang, G.; Truong, L. D.; Timme, T. L.; Ren, C.; Wheeler, T. M.; Park, S. H.; Nasu, Y.; Bangma, C. H.; Kattan, M. W.; Scardino, P. T.; Thompson, T. C. Elevated expression of caveolin is associated with prostate and breast cancer. Clin. Cancer Res., 1998, 4(8), 1873-80.

[15] Tahir, S. A.; Yang, G.; Ebara, S.; Timme, T. L.; Satoh, T.; Li, L.; Goltsov, A.; Ittmann, M.; Morrisett, J. D.; Thompson, T. C. Se- creted caveolin-1 stimulates cell survival/clonal growth and contributes to metastasis in androgen-insensitive prostate cancer. Cancer Res., 2001, 61(10), 3882-5.

[16] Wikman, H.; Seppanen, J. K.; Sarhadi, V. K.; Kettunen, E.; Salmenkivi, K.; Kuosma, E.; Vainio-Siukola, K.; Nagy, B.; Karjalainen, A.; Sioris, T.; Salo, J.; Hollmen, J.; Knuutila, S.; Anttila, $\mathrm{S}$. Caveolins as tumour markers in lung cancer detected by combined use of cDNA and tissue microarrays. J. Pathol., 2004, 203(1), 584-93.

[17] Drucker, B. J. Renal cell carcinoma: current status and future prospects. Cancer Treat Rev., 2005, 31 (7), 536-45.

[18] Ticozzi-Valerio, D.; Pitto, F.R.M.; Rocco, F.; Bosari, S.; Perego, R.; Sarto, C.; Di Fonzo, A.; Bosso, N.; Mocarelli, P.; Galli-Kienle, M.; Magni, F. Differential expression of AQP1 in microdomainenriched membranes of renal cell carcinoma. Proteomics Clin. Appl., 2007, 1(6), 588-97.

[19] Banfi, C.; Brioschi, M.; Wait, R.; Begum, S.; Gianazza, E.; Fratto, P.; Polvani, G.; Vitali, E.; Parolari, A.; Mussoni, L.; Tremoli, E. Proteomic analysis of membrane microdomains derived from both failing and non-failing human hearts. Proteomics, 2006, 6(6), 197688 .

[20] Lopez-Beltran, A.S.M.; Montironi, R.; Kirkali, Z. 2004 WHO classification of the renal tumors of the adults. Eur. Urol., 2006 , 49(5), 798-805.

[21] Novara, G.; Martignoni, G.; Artibani, W.; Ficarra, V. Grading systems in renal cell carcinoma. J. Urol., 2007, 177 (2), 430-6.

[22] Haeffner, E.W.; Kolbe, K.; Schroeter, D.; Paweletz, N. Plasma membrane heterogeneity in ascites tumor cells. Isolation of a light and a heavy membrane fraction of the glycogen-free Ehrlich-Lettre substrain. Biochim. Biophys. Acta, 1980, 603(1), 36-51.

[23] Sargiacomo, M.; Sudol, M.; Tang, Z.; Lisanti, M.P. Signal transducing molecules and glycosyl-phosphatidylinositol-linked proteins form a caveolin-rich insoluble complex in MDCK cells. J. Cell Biol., 1993, 122 (4), 789-807.

[24] Sanchez, J. C.; Hochstrasser, D.; Rabilloud, T. In-gel sample rehydration of immobilized pH gradient. Methods Mol. Biol., 1999, 112, 221-5.

[25] Daffara, R.; Botto, L.; Beretta, E.; Conforti, E.; Faini, A.; Palestini, P.; Miserocchi, G. Endothelial cells as early sensors of pulmonary interstitial edema. J. Appl. Physiol., 2004, 97(4), 1575-83.

[26] Palestini, P.; Pitto, M.; Tedeschi, G.; Ferraretto, A.; Parenti, M.; Brunner, J.; Masserini, M. Tubulin anchoring to glycolipidenriched, detergent-resistant domains of the neuronal plasma membrane. J. Biol. Chem., 2000, 275(14), 9978-85.

[27] Sadler, S. E. Low-density caveolae-like membrane from Xenopus laevis oocytes is enriched in Ras. J. Cell Biochem., 2001, 83, (1), 21-32.

[28] Kogo, H.; Aiba, T.; Fujimoto, T. Cell type-specific occurrence of caveolin-1alpha and -1beta in the lung caused by expression of distinct mRNAs. J. Biol. Chem., 2004, 279(24), 25574-81.

[29] Raimondo, F.; Ceppi, P.; Guidi, K.; Masserini, M.; Foletti, C.; Pitto, M. Proteomics of plasma membrane microdomains. Expert Rev. Proteomics, 2005, 2(5), 793-807.

[30] Lisanti, M. P.; Scherer, P. E.; Vidugiriene, J.; Tang, Z.; Hermanowski-Vosatka, A.; Tu, Y. H.; Cook, R. F.; Sargiacomo, M. Characterization of caveolin-rich membrane domains isolated from an endothelial-rich source: implications for human disease. J. Cell Biol., 1994, 126(1), 111-26.

[31] Parkin, E. T.; Turner, A. J.; Hooper, N. M. Differential effects of glycosphingolipids on the detergent-insolubility of the glycosylphosphatidylinositol-anchored membrane dipeptidase. Biochem. J., 2001, 358(Pt 1), 209-16.

[32] Schmitz, G.; Orso, E. CD14 signalling in lipid rafts: new ligands and co-receptors. Curr. Opin. Lipidol., 2002, 13 (5), 513-21.

[33] Sprenger, R. R.; Fontijn, R. D.; van Marle, J.; Pannekoek, H.; Horrevoets, A. J. Spatial segregation of transport and signalling functions between human endothelial caveolae and lipid raft proteomes. Biochem. J., 2006, 400(3), 401-10.

[34] Pechlivanis, M.; Kuhlmann, J. Hydrophobic modifications of Ras proteins by isoprenoid groups and fatty acids--More than just membrane anchoring. Biochim. Biophys. Acta, 2006, 1764(12), 1914-31. 
[35] Takashi, M.; Sakata, T.; Inaguma, Y.; Kato, K. Elevated concentrations of gamma-enolase in renal cell tumors in rats: similarity to renal cell carcinoma in man. Urol. Res., 1996, 24(6), 375-9.

[36] Pinder, S. E.; Balsitis, M.; Ellis, I. O.; Landon, M.; Mayer, R. J.; Lowe, J. The expression of alpha B-crystallin in epithelial tumours: a useful tumour marker? J. Pathol., 1994, 174(3), 209-15.

[37] Zatyka, M.; da Silva, N. F.; Clifford, S. C.; Morris, M. R.; Wiesener, M. S.; Eckardt, K. U.; Houlston, R. S.; Richards, F. M.; Latif, F.; Maher, E. R. Identification of cyclin D1 and other novel targets for the von Hippel-Lindau tumor suppressor gene by expression array analysis and investigation of cyclin D1 genotype as a modifier in von Hippel-Lindau disease. Cancer Res., 2002, 62(13), 3803-11.

[38] Grandinetti, C. A.; Goldspiel, B. R. Sorafenib and sunitinib: novel targeted therapies for renal cell cancer. Pharmacotherapy, 2007, 27(8), 1125-44.

[39] Yoo, S. H.; Park, Y. S.; Kim, H. R.; Sung, S. W.; Kim, J. H.; Shim, Y. S.; Lee, S. D.; Choi, Y. L.; Kim, M. K.; Chung, D. H. Expression of caveolin-1 is associated with poor prognosis of patients with squamous cell carcinoma of the lung. Lung Cancer, 2003, 42(2), 195-202.

[40] Campbell, L.; Gumbleton, M.; Griffiths, D. F. Caveolin-1 overexpression predicts poor disease-free survival of patients with clinically confined renal cell carcinoma. Br. J. Cancer, 2003, 89(10), 1909-13.

[41] Carrion, R.; Morgan, B. E.; Tannenbaum, M.; Salup, R.; Morgan, M. B. Caveolin expression in adult renal tumors. Urol. Oncol., 2003, 21(3), 191-6.

[42] Horiguchi, A.; Asano, T.; Asakuma, J.; Asano, T.; Sumitomo, M.; Hayakawa, M. Impact of caveolin-1 expression on clinicopathological parameters in renal cell carcinoma. J. Urol., 2004, 172(2), 718-22.

[43] Joo, H. J.; Oh, D. K.; Kim, Y. S.; Lee, K. B.; Kim, S. J. Increased expression of caveolin-1 and microvessel density correlates with metastasis and poor prognosis in clear cell renal cell carcinoma. BJU Int., 2004, 93(3), 291-6.

[44] Takehara, K.; Sakai, H.; Koga, S.; Kanetake, H. Immunohistochemical expression of caveolin-1 as a marker for the biological potential of renal cell carcinoma. J. Urol., 2002, 167(Suppl.), 132.

[45] Campbell, L.; Jasani, B.; Edwards, K.; Gumbleton, M.; Griffiths, D. F. Combined expression of caveolin-1 and an activated AKT/mTOR pathway predicts reduced disease-free survival in clinically confined renal cell carcinoma. Br. J. Cancer, 2008, 98(5), 931-40.

[46] Liu, P.; Rudick, M.; Anderson, R. G. Multiple functions of caveolin-1. J. Biol. Chem., 2002, 277(44), 41295-8.

[47] Uittenbogaard, A.; Ying, Y.; Smart, E. J. Characterization of a cytosolic heat-shock protein-caveolin chaperone complex. Involvement in cholesterol trafficking. J. Biol. Chem., 1998, 273(11), 6525-32.

[48] Jiang, M.; Jia, L.; Jiang, W.; Hu, X.; Zhou, H.; Gao, X.; Lu, Z.; Zhang, Z. Protein disregulation in red blood cell membranes of type 2 diabetic patients. Biochem. Biophys. Res. Commun., 2003, 309(1), 196-200.

[49] Nagao, E.; Seydel, K. B.; Dvorak, J. A. Detergent-resistant erythrocyte membrane rafts are modified by a Plasmodium falciparum infection. Exp. Parasitol., 2002, 102(1), 57-9.

[50] Santamaria, A.; Castellanos, E.; Gomez, V.; Benedit, P.; RenauPiqueras, J.; Morote, J.; Reventos, J.; Thomson, T. M.; Paciucci, R. PTOV1 enables the nuclear translocation and mitogenic activity of flotillin-1, a major protein of lipid rafts. Mol. Cell Biol., 2005, 25(5), 1900-11.

[51] Braun, R. J.; Kinkl, N.; Beer, M.; Ueffing, M. Two-dimensional electrophoresis of membrane proteins. Anal. Bioanal. Chem., 2007, $389(4), 1033-45$

(C) Raimondo et al.; Licensee Bentham Open.

This is an open access article licensed under the terms of the Creative Commons Attribution Non-Commercial License (http://creativecommons.org/licenses/ by-nc/3.0/) which permits unrestricted, non-commercial use, distribution and reproduction in any medium, provided the work is properly cited. 